\begin{tabular}{|l|l|l||}
\hline \multicolumn{2}{|c|}{ PublisherInfo } \\
\hline \hline PublisherName & $:$ & BioMed Central \\
\hline \hline PublisherLocation & $:$ & London \\
\hline \hline PublisherImprintName & $:$ & BioMed Central \\
\hline \hline
\end{tabular}

\title{
Man's best genome?
}

\begin{tabular}{|l|l|l||}
\hline \multicolumn{2}{|c|}{ ArticleInfo } \\
\hline \hline ArticleID & $:$ & 5047 \\
\hline \hline ArticleDOI & $:$ & $10.1186 /$ gb-spotlight-20051209-01 \\
\hline \hline ArticleCitationID & $:$ & spotlight-20051209-01 \\
\hline \hline ArticleSequenceNumber & $:$ & 110 \\
\hline \hline ArticleCategory & $:$ & Research news \\
\hline ArticleFirstPage & $:$ & 1 \\
\hline \hline ArticleLastPage & $:$ & 3 \\
\hline \hline & & RegistrationDate : 2005-12-9 \\
\hline ArticleHistory & $:$ & OnlineDate \\
\hline \hline ArticleCopyright & $:$ & BioMed Central Ltd2005-12-9 \\
\hline \hline ArticleGrants & $:$ & \\
\hline \hline ArticleContext & $:$ & 130595511 \\
\hline \hline
\end{tabular}




\section{Aileen Constans}

Email: aconstans@the-scientist.com

Researchers released the draft genome sequence of the domestic dog in this week's issue of Nature, capping a multiyear project aimed at mapping genetic traits in man's best friend, and producing the highest-resolution draft to date of the canine genome. Scientists say they hope the latest addition to the genomic toolbox will serve as a particularly useful model for studying human diseases, given that hundreds of years of dog inbreeding has produced isolated subpopulations whose physical traits are easily linked to genetic structures.

The study authors have "pretty much unlocked a treasure chest of genetic variability that underlies phenotypic variability, that helps us to understand not only what regulates traits in dogs but also what regulates traits in humans," canine geneticist Patrick Venta of Michigan State University, who was not involved in the study, told The Scientist. "There's no other mammalian species that has as much genetic variability that causes so much phenotypic variability."

The assembled sequence, which spans $2.41 \mathrm{Gbp}$, represented $99 \%$ of the genome of a female boxer named Tasha, who was chosen for the study because genetic marker assays showed she was highly inbred.

A previous survey sequence of a male standard poodle provided enough information for comparative genomic studies. But the relatively low coverage (roughly 75\%) meant that there were a lot of gaps in the sequence. "Occasionally you get a gap that's too big" with lower coverage, said Venta. In the current study, there are much fewer gaps in coverage, "which makes it so much easier for us to just go in and identify a gene that we want to study." Venta is currently using the data to identify sequences underlying behavioral phenotypes.

The authors performed a cross-breed analysis of SNP distribution to determine the amount of haplotype sharing within and across breeds, generating a 2.5 million SNP map with an average density of $1 \mathrm{SNP}$ per $1,000 \mathrm{bp}$. They used this map to compare regions of the boxer sequence with those of nine other breeds, and found that within-breed linkage disequilibrium extends over a 50 -fold greater distance than in humans. This suggests that association studies in dog would require only 10,000 evenly-based SNPs, compared to 300,000 in humans. The authors also assembled a population genetic history of domestic dogs, which demonstrated that two bottlenecks - divergence from wolves and the creation of individual breeds - likely determined the haplotype structure of the modern canine genome.

"We know that we can use many fewer SNPs to map disease genes or traits of interest in dogs than in humans, because blocks of the genome that are inherited through multiple generations, in families, are much larger in dogs than they are in humans," said co-author Elaine Ostrander of the National Human Genome Research Institute (NHGRI), Bethesda, Md.

The authors also compared the human, mouse, and dog sequences and found a common set of genes representing roughly $5 \%$ of the human genome. "The very most conserved sections that we found reside in the proximity of developmental genes, suggesting that we have found new regulatory elements in the human genome," said co-author Kerstin Lindblad-Toh of the Broad Institute at the Massachusetts Institute of Technology. "We now also know that it should be relatively straightforward to find disease genes in dogs," she added. 
Relative to humans, dogs have less DNA in their genomes and appear to have fewer genes. They have 39 chromosomes.

The American Kennel Club Canine Health Foundation has offered close to \$2 million over the last decade to projects supporting sequencing efforts. The current study was funded by NHGRI, which provided roughly $\$ 30$ million. "We're very excited about the fact that we've now essentially reached completion" of the project, said Ronna Dornsife, research grants administrator for the AKCCHF.

\section{References}

1. K. Lindblad-Toh et al., "Genome sequence, comparative analysis and haplotype structure of the domestic dog," Nature, Dec. 8, 2005., [http://www.nature.com]

2. I.Oransky, "First dog cloned," The Scientist, August 3, 2005., [http://www.the-scientist.com/news/ 20050803/01]

3. Patrick Venta, [http://mmg.msu.edu/faculty/venta.htm]

4. E.F. Kirkness et al., "The dog genome: Survey sequencing and comparative analysis," Science, September 26, 2003.

5. C. Holding, "Barking up the right tree," The Scientist, September 26, 2003., [http://www.thescientist.com/news/20030926/02]

6. Elaine Ostrander, [http://www.genome.gov/12513335]

7. Kerstin Lindblad-Toh, [http://www.broad.mit.edu/about/bios/bio-lindblad-toh.html]

8. American Kennel Club Canine Health Foundation, [http://www.akcchf.org/]

This PDF file was created after publication. 